BIOMEDICAL AND BIOSOCIAL ANTHROPOLOGY
$\begin{gathered}\text { Official Journal of the International Academy } \\ \text { of Integrative Anthropology } \\ \text { journal homepage: http://bba-journal.com }\end{gathered}$

\title{
Peculiarities of the chest's size in female volleyball players of different constitutional types
}

Sarafyniuk L. A. ${ }^{1}$, Pivtorak V. I., Khavtur V. O.. ${ }^{2}$ Fedoniuk L. la.. ${ }^{2}$ Khapitska O. P.

${ }^{1}$ National Pirogov Memorial Medical University, Vinnytsya, Ukraine

${ }^{2}$ SHEI "I. Ya. Horbachevsky Ternopil State Medical University of the Ministry of Health of Ukraine", Ternopil, Ukraaine

\section{ARTICLE INFO}

Received: 7 September, 2018

Accepted: 8 November, 2018

UDC: 572.5:796.325-05:611.018.2

\section{CORRESPONDING AUTHOR}

e-mail: Isarafinyuk@gmail.com Sarafyniuk L.A.
During qualified sport selection special attention should be paid to those features and abilities that have a great influence on the effectiveness, and those, that are mainly under the influence of genetic factor. Such morphogenetic markers of sports selection include, firstly, the constitutional features of athletes, in particular the shape of the chest. The purpose of work is to determine the differences between the anthropometric dimensions of the chest between female volleyball players of high level of athletic skill and non-sportsmen, who belonged to different constitutional types. On the base of the Scientific-Research Center of the Vinnytsya National Pirogov Memorial Medical University an anthropo-somatotypological investigation of 113 female volleyball players of high level athletic skill (from 16 to 20 years old) was done. The control group included 204 practically healthy young women, who were not engaged in sports of the corresponding age. Anthropometric research was performed according to the V. V. Bunak (1941) method, somatotypological study was based on the estimated modification of the Heath-Carter method (1990). In young women, who were not engaged in sports, more than in half of the cases were indicated constitutional types, which were characterized by good development of fatty body composition. Between female volleyball players were dominated individuals with mesomorphic somatotype (26.66\%), ectomorphic somatotype (23.01\%), ectomesomorphic somatotype (23.89\%), and representatives of the intermediate somatotype (23.01\%) were almost uniformly represented in the sample. The analysis of the results was carried out in the licensing program "Statistica 5.5" using nonparametric methods of estimating the parameters. We have found that the female volleyball players of the ectomorphic somatotype have the smallest anthropometric dimensions of the chest, as compared with athletes of other constitutional groups. In the mesomorphs female volleyball players all transverse and the most of overall sizes of the chest were the largest. Parameters of the athletes with the ecto-mesomorphic somatotype were slightly small to the size of the somatometric parameters of the mesomorphs, but they had the highest values of the anterior-posterior size of the chest. Female volleyball players with intermediate somatotype had larger values of the chest size than volleyball players with ectomorphic somatotype, although no significant difference was found when comparing them. It was found, that the most of the overall, transverse, and anterior-posterior dimensions of the chest in female volleyball players are statistically significantly higher than that of girls, who were not engaged in sports, and belonged to the same constitutional type as athletes. We have made a conclusion that belonging to one of the constitutional type does not provide similarity of morphometric parameters of the chest in persons with different levels of physical activity.

Keywords: chest, anthropometry, somatotype, female volleyball players, juvenile age.

\section{Introduction}

During a qualified sport selection, special attention should be paid to those features and abilities, that have a great influence on the effectiveness, and those, that are mainly under the influence of genetic factor $[5,8,9,10,13,21,22$, 25]. Among the morphogenetic factors that determine sports abilities, somatometric parameters play an important role 
$[14,18,19]$. They have influence on the efficiency of energy supply systems, physical capacity, intensity of recovery, development of physical qualities and the nature of adaptation processes [24, 26]. These morphogenetic markers of sports selection, in the first place, include the constitutional features of athletes [7, 15]. Constitution is the complex of morphofunctional features of the organism, which is formed under the influence of the genotype and is modified by exogenous influences, among which the peculiarities of the particular sport activity are acquired [17]. Taking into account somatotypological affiliation of a person it is possible to indicate the time of puberty and aging, as well as to predict the influence of various environmental factors on the organism [1]. In various techniques of somatotyping, the following four features are taken into account, such as the development of the fat, bone and muscle components of body weight and human proportions, which, in particular, are determined by the shape of the chest. Anatomy of the human chest skeleton at various stages of ontogenesis (neonatal period, childhood, mature age) was of interest to many researchers $[4,11,23]$. In addition, in the literature there is evidence of differences in some parameters of the chest in individuals with a certain constitutional type. In most cases, these studies addressed to the children and persons of the youth age $[6,16]$. L. V. Muzurova [12] was made morphometry of the body with the study of various parameters of the chest, such as the anterior-posterior, transverse size, anterior and posterior chest length in young men of 17-19 years of different types of constitution. But features of the chest in female athletes of high level of skills, which would belong to different constitutional types, are scarce.

The purpose of our work is to determine the differences between the anthropometric dimensions of the chest between female volleyball players of high level of athletic skill and non-sportsmen, who belonged to different constitutional types.

\section{Materials and methods}

On the base of the Scientific-Research Center of the Vinnytsya National Pirogov Memorial Medical University a comprehensive survey of 113 female volleyball players of high level athletic skill (from 16 to 20 years old) was done. Sports experience in all volleyball players is more than 3 years. The control group included 204 practically healthy young women, who were not engaged in sports of the corresponding age.

Anthropometric research was performed according to the V. V. Bunak [2] method, somatotypological study was based on the estimated modification of the Heath-Carter method [3]. After the somatotyping, it was found, that 29 female volleyball players and 36 non-sports young women belonged to the mesomorphic type of constitution. To ectomorphs were included 26 female volleyball players and 39 young women of the control group; to ecto-mesomorphs - 27 female volleyball players and 14 young women of the control group, to the middle intermediate type - 26 female volleyball players and 64 young women of the control group; to the endomesomorphs - 5 female volleyball players and 41 control young women, 10 control group young women belonged to the endomorphic somatotype. In the reason that the group of endo-mesomorphs among volleyball players was small, we did not study the constitutional features of the chest in this somatotype.

The analysis of the results was carried out in the licensing program "Statistica 5.5" using nonparametric methods of estimating the parameters. The reliability of the difference between the parameters was determined using the ManWhitney U-criterion.

\section{Results}

After the somatotypological analysis of the overall dimensions of the chest (Table 1), it was found, that female volleyball players of the mesomorphic, ectomorphic, ectomesomorphic and intermediate types had a statistically significantly larger parameter of the chest girth during inspiration, than young women in the control group of the same somatotype (in all cases $p<0.001$ ). This anthropometric dimension is the largest in the female volleyball players of the mesomorphic somatotype, the smallest in athletes of ectomorphs. Significant differences were found when comparing female volleyball players with an ectomorphic type with athletes of mesomorphic and ecto-mesomorphic somatotypes (in both cases $p<0.01$ ).

The crossover size of the chest on expiration in mesomorphs female volleyball players is significantly lower, than in the control group $(p<0.001)$. Athletes of the ectomorphic $(p<0.001)$, ecto-mesomorphic $(p<0.001)$ and intermediate $(p<0.01)$ constitutional types have a larger girth of the chest on expiration, than girls of control groups. There are no established somatotypological differences in the level of this size of the chest when comparing groups of female volleyball players that belonged to different constitutional types (see Table 1).

The crossover size of the chest during rest at female volleyball players of different somatotypes is significantly higher, than that of control group young women (in all cases $\mathrm{p}<0.001)$. This size is the largest in the group of female volleyball players of mesomorphs. Parameters in the athletes of the ecto-mesomorphic and intermediate type are slightly smaller to the size of the chest girth at rest, and the ectomorphic female volleyball players have the smallest given size. Significant differences were found, when comparing volleyball players with an ectomorphic type with athletes of mesomorphic and ecto-mesomorphic somatotypes (in both cases $p<0.05$ ) (see Table 1 ).

It was found that the medium sternal diameter of the mesomorphic, ectomorphic, ecto-mesomorphic and intermediate somatotypes of female volleyball players is significantly higher $(p<0.01-0.001)$, than that of young women of the same somatotype, who were not engaged in sports (respectively $26.60 \pm 1.55 \mathrm{~cm}$ and $25.54 \pm 2.96 \mathrm{~cm}$ in 
Table 1. Features of the overall dimensions of the chest in female volleyball players of different somatotypes $(\mathrm{M} \pm \sigma, \mathrm{cm})$.

\begin{tabular}{|c|c|c|c|c|c|}
\hline Parameters & Group & $\mathrm{M} \pm \sigma$ & $p_{1}$ & $\mathrm{p}_{2}$ & $p_{3}$ \\
\hline \multirow{8}{*}{$\begin{array}{l}\text { Chest during } \\
\text { inspiration }\end{array}$} & $M_{c}$ & $95.05 \pm 5.99$ & & $<0.01$ & $>0.05$ \\
\hline & $M_{k}$ & $86.46 \pm 7.14^{\star \star \star}$ & & & \\
\hline & $\mathrm{L}_{\mathrm{c}}$ & $90.38 \pm 6.73$ & $<0.01$ & & $<0.01$ \\
\hline & $L_{k}$ & $82.67 \pm 5.12^{\star \star *}$ & & & \\
\hline & L-M & $94.78 \pm 4.04$ & $>0.05$ & $<0.01$ & \\
\hline & L-M & $84.82 \pm 6.83^{* * *}$ & & & \\
\hline & $\mathrm{S}_{\mathrm{c}}$ & $92.73 \pm 6.10$ & $>0.05$ & $>0.05$ & $>0.05$ \\
\hline & $\mathrm{S}_{\mathrm{k}}$ & $86.42 \pm 4.99^{\star * *}$ & & & \\
\hline \multirow{8}{*}{$\begin{array}{c}\text { Chest during } \\
\text { expiration }\end{array}$} & $M_{c}$ & $85.94 \pm 6.34$ & & $>0.05$ & $>0.05$ \\
\hline & $M_{k}$ & $86.46 \pm 7.14^{\star \star *}$ & & & \\
\hline & $\mathrm{L}_{\mathrm{c}}$ & $83.09 \pm 6.05$ & $>0.05$ & & $>0.05$ \\
\hline & $\mathrm{L}_{\mathrm{k}}$ & $76.14 \pm 5.18^{\star \star *}$ & & & \\
\hline & $L-M_{c}$ & $86.00 \pm 4.67$ & $>0.05$ & $>0.05$ & \\
\hline & $L-M_{K}$ & $77.34 \pm 5.86^{* * *}$ & & & \\
\hline & $S_{c}$ & $84.27 \pm 5.86$ & $>0.05$ & $>0.05$ & \\
\hline & $S_{k}$ & $80.20 \pm 5.00^{* *}$ & & & \\
\hline \multirow{8}{*}{$\begin{array}{l}\text { Chest during } \\
\text { rest }\end{array}$} & $M_{c}$ & $89.94 \pm 6.29$ & & $<0.05$ & $>0.05$ \\
\hline & $M_{k}$ & $82.07 \pm 6.60^{\star \star \star}$ & & & \\
\hline & $\mathrm{L}_{\mathrm{c}}$ & $85.94 \pm 6.60$ & $<0.05$ & & $<0.05$ \\
\hline & $L_{k}$ & $78.06 \pm 4.90^{\star * *}$ & & & \\
\hline & $L-M_{c}$ & $89.33 \pm 4.40$ & $>0.05$ & $<0.05$ & \\
\hline & $L-M_{k}$ & $80.37 \pm 6.14^{* * *}$ & & & \\
\hline & $\mathrm{S}_{\mathrm{c}}$ & $87.86 \pm 6.16$ & $>0.05$ & $>0.05$ & $>0.05$ \\
\hline & $S_{k}$ & $82.08 \pm 4.77^{\star \star *}$ & & & \\
\hline
\end{tabular}

Notes: $M_{c}$ - mesomorphs female volleyball players, $M_{k}$ - control group of mesomorphs somatotype, $L_{c}$ - ectomorphic female volleyball players, $L_{K}$ - control group of ectomorphic somatotype, $L-M_{c}$ - ecto-mesomorphic female volleyball players, $L-M_{k}$ - control group of ecto-mesomorphic somatotype, $S_{c}$ - female volleyball players of the intermediate somatotype, $S_{k}$ - control group of female volleyball players of the intermediate somatotype; $p_{1}$ - the indicator of the statistical significance of the difference in anthropometric parameters between mesomorphs athletes and other groups of female volleyball players, $p_{2}$ - the indicator of the statistical significance of the difference in anthropometric parameters between ectomorphic female volleyball players and other groups of volleyball players, $p_{3}$ - the indicator of the statistical significance of the difference in anthropometric parameters between ectomesomorphic female volleyball players and other groups of athletes, * - the indicator of the significance of the difference in anthropometric parameters between individuals of the same somatotype in $p<0.05$, ** - the indicator of the significance of the difference in anthropometric parameters between individuals of the same somatotype in $\mathrm{p}<0.01,{ }^{* * *}$ - the indicator of the significance of the difference in anthropometric parameters between individuals of the same somatotype in $p<0.001$.

mesomorphs, $25.38 \pm 1.71 \mathrm{~cm}$ and $24.38 \pm 2.95 \mathrm{~cm}$ in ectomorphs, $26.70 \pm 1.37 \mathrm{~cm}$ and $24.32 \pm 1.33 \mathrm{~cm}$ in ectomesomorphs, $23.85 \pm 2.45 \mathrm{~cm}$ and $20.68 \pm 1.50 \mathrm{~cm}$ in the representatives of the intermediate somatotype). In addition, it was found, that this size of the chest in female volleyball players of the ectomorphic somatotype is significantly larger, than that of athletes with mesomorphic $(p<0.05)$ and ectomesomorphic $(p<0.01)$ constitutional types.

Inferior sternal diameter in the female volleyball players of the mesomorphic, ectomorphic, ecto-mesomorphic and intermediate somatotypes is statistically significantly higher $(p<0.001)$, than that of young men, who were not engaged in sports of the same somatotype $(23.67 \pm 2.31 \mathrm{~cm}$ respectively and $21.15 \pm 3.38 \mathrm{~cm}$ in mesomorphs; $22.48 \pm 1.40 \mathrm{~cm}$ and $20.14 \pm 3.21$ in ectomorphs, $23.87 \pm 1.74 \mathrm{~cm}$ and $20.32 \pm$ $1.55 \mathrm{~cm}$ in ecto-mesomorphs, $23.85 \pm 2.45 \mathrm{~cm}$ and $20.68 \pm$ $1.50 \mathrm{~cm}$ in the representatives of the intermediate somatotype). It was revealed, that in female volleyball players of the ectomorph somatotype the inferior sternal diameter has the smallest value in comparison with athletes of other constitutional types; statistically significant differences were observed between them and athletes of mesomorphic $(p<0.05)$ and ecto-mesomorphic $(p<0.01)$ types. In female volleyball players of the intermediate somatotype, the parameters of the inferior sternal diameter size are also greater than that of ectomorphs.

Anterior-posterior medium sternal size in female volleyball players of mesomorphic and ecto-mesomorphic somatotypes is statistically significantly higher $(p<0.05)$, than in young women of the same somatotype who were not engaged sport $(18.17 \pm 2.02 \mathrm{~cm}$, respectively, and $16.95 \pm$ $1.20 \mathrm{~cm}$ in mesomorphs, $18.46 \pm 3.20 \mathrm{~cm}$ and $16.82 \pm 1.46$ $\mathrm{cm}$ in ecto-mesomorphs). There were no significant differences between female volleyball players of the ectomorphic or intermediate somatotype and girls of the corresponding somatotypes, that were not engaged in sports (respectively $17.75 \pm 3.59 \mathrm{~cm}$ and $16.72 \pm 1.91 \mathrm{~cm}$ in ectomorphs, $16.90 \pm 2.00 \mathrm{~cm}$ and $16.70 \pm 1.28 \mathrm{~cm}$ in the representatives of the intermediate somatotype). The largest values of the anterior-posterior medium sternal size were found in athletes with an ecto-mesomorphic somatotype, but this group of athletes was the most heterogeneous in the value of this parameter, so there were no reliable differences when compared with the female volleyball players of other somatotypes.

There were no significant differences in the width of the shoulders between the female volleyball players of the mesomorphic, ectomorphic, ecto-mesomorphic or intermediate somatotypes and young women of the corresponding non-sports somatotypes $(36.62 \pm 2.16 \mathrm{~cm}$, respectively, and $35.87 \pm 2.66 \mathrm{~cm}$ in the mesomorphs, 35.69 $\pm 2.52 \mathrm{~cm}$ and $35.98 \pm 2.32 \mathrm{~cm}$ in ectomorphs, $36.28 \pm 2.00$ $\mathrm{cm}$ and $35.75 \pm 2.02 \mathrm{~cm}$ in ecto-mesomorphs, $36.44 \pm 2.71$ $\mathrm{cm}$ and $35.90 \pm 2.77 \mathrm{~cm}$ in the representatives of the intermediate somatotype). Also, there are no significant differences in the comparison of athletes of different somatotypes.

\section{Discussion}

After somatotyping, we found, that female volleyball players belonged to the five constitutional types, while non- 
sports girls belonged to six types of constitution. In young women, the control group is dominated by individuals with the intermediate somatotype $(31.40 \%)$, with a high incidence of individuals with an endo-mesomorphic type (20.09\%), and $4.90 \%$ - endomorphic type. Mesomorphic (17.64\%) and ectomorphic (19.11\%) types in this group occur almost with the same frequency, and the ecto-mesomorphic somatotype is found in $6.89 \%$ of cases. Thus, in young women, who were not engaged in sports, in more than half of the cases there are constitutional types, for which the good development of the fatty component of body composition is a characteristical feature. Female volleyball players are dominated by individuals with mesomorphic somatotype (26.66\%), and ectomorphs (23.01\%), ecto-mesomorphs $(23.89 \%)$, and representatives of the intermediate somatotype $(23.01 \%)$ in the sample are almost uniformly represented; an endo-mesomorphic somatotype was found in $4.42 \%$. J. Lewandowska and others [7] proved, that adaptation to physical activity during the training process and taking into account the demands of sports selection in a particular sport, leads to a decrease in the varieties of somatotypes in comparison with the non-sports population. High-level athletes in different types of sport, which include volleyball, where stature is one of the most important factors affecting the outcome, are showed the greatest similarity to morphological characteristics and motor abilities. These qualities of athletes can be the basis for creating a somatic and physical "model" for this discipline.

The shape and size of the chest determine not only the somatotypological affiliation [16], but also have a significant role among other morphological indicators for predicting sports fitness. This is confirmed by Tkachuk M. G. and Sobolev A. A. [24], who discovered, that the overall parameters of the chest were significantly large for determining the fitness of the Sambs as length of their leg, the girth of arms and shoulders, correlation between the lengths of the leg and the length of the thigh, correlation between the length of the forearm and the shoulder length.

We found, that most of the overall, transverse and anteriorposterior dimensions of the chest in female volleyball players were statistically significantly higher, than that of young women, who were not engaged in sports, and belonged to the same constitutional type as athletes. An exception to this feature are only two anthropometric dimensions: the width of the shoulders, which does not have a significant difference between any of the comparison groups, and the girth of the chest during expiration in the

\section{References}

[1] Badenhorst, L., De Ridder, J. H., \& Underhay, C. (2003). Somatotype, blood pressure and physical activity among 10to 15-year old south African boys: the THUSA BANA study. African Journal for Physical Activity and Health Sciences, 9(3), 184-195

[2] Bunak, V. V. (1941). Anthropometry: a practicalcourse. M.: Uchpedgiz.

[3] Carter, J. L., \& Heath, B. H. (1990). Somatotyping - development volleyball players of the mesomorphic somatotype, which is significantly lower than in the control. We think that lower values of this size are the positive adaptation mechanism of changes. It is so, because only in mesomorphs, which are characterized by a predominant development of the muscular component of the somatotype, a decrease in the chest girth during expiration and an increase in this case the parameters during inspiration indicates a great excursion of the chest. In our previous studies [20], it was also found, that mesomorphs female volleyball players, that there were a significantly larger parameters of the length, body mass, body surface area and another body sizes, than in young women in the same somatotype, who were not engaged in sport. Thus, we can conclude, that belonging to one constitutional type, does not provide a similarity of morphometric parameters of the chest in persons with different levels of physical activity.

In addition, we found, that the female volleyball players of the ectomorphic somatotype have the smallest anthropometric dimensions of the chest, compared with athletes of other constitutional groups. In the mesomorphs female volleyball players all transverse, most overall sizes of the chest are the greatest. Parameters of the athletes with an ecto-mesomorphic somatotype are slightly small to the size of the somatometric parameters of the mesomorphs, but they have the largest values of the anterior-posterior size of the chest. Female volleyball players with intermediate somatotype have larger values of the size of the chest, than female volleyball players with an ectomorphic somatotype, although no significant difference in their comparison was found.

Using of the somatotypological method during analyzing of the external body parameters will allow more accurate prediction of changes in anthropometric parameters of volleyball players under the influence of training-competitive activities.

\section{Conclusions}

1. In female volleyball players of mesomorphic, ectomorphic, ecto-mesomorphic and intermediate somatotypes compared to young women, who are not engaged in sports of the same constitutional type, are indicated significantly larger somatometric parameters of the chest, except for shoulder width.

2. A large number of the anthropometric dimensions of the chest in female volleyball players of an ectomorphic somatotype are significantly less than female volleyball players of mesomorphic and ecto-mesomorphic types.

and applications. Cambridge: University Press.

[4] Gadilshina, I. R., \& Lyaschenko, D. N. (2015). Anatomy of the skeleton of the human thorax in the early fetal period of ontogenesis. Modern problems of science and education, 4. http://www.science-education. ru/ru/article/view?id=20506

[5] Guilherme, J. P. L. F., Tritto, A. C. C., North, K. N., Lancha Junior, A. H., \& Artioli, G. G. (2014). Genetics and sport performance: current challenges and directions to the future. Revista 
Brasileira de Educacao Fisica e Esporte, 28(1), 177-193. http://dx.doi.org/10.1590/S1807-55092014000100177

[6] Komolkin, I. A., Afanasev, A. P., \& Schegolev, D. V. (2012). The role of heredity in the origin of congenital deformities of the chest. Genius Orthopedics, 2, 152-156.

[7] Lewandowska, J., Busko, K., Pastuszak, A., \& Boguszewska, K. (2011). Somatotype variables related to muscle torque and power in judoists. Journal of Human Kinetics, 30, 21-28. doi: 10.2478/v10078-011-0069-y

[8] Lippi, G., Maffulli, N., \& Longo, U. G. (2009). Genetics and sports. British Medical Bulletin, 93(1), 27-47. doi: 10.1093/ $\mathrm{bmb} / \mathrm{ldp} 007$

[9] Liu, J., Lewis, G., \& Evans, L. (2013). Understanding aggressive behaviour across the lifespan. Journal of psychiatric and mental health nursing, 20(2), 156-168. doi: 10.1111/j.13652850.2012.01902.x

[10] Malina, R. M. (2010). Early sport specialization: roots, effectiveness, risks. Current sports medicine reports, 9(6), 364-371. doi: 10.1249/JSR.0b013e3181fe3166

[11] Miyazaki, O., Nishimura, G., Sago, H., Horiuchi, T., Hayashi, S., \& Kosaki, R. (2012). Prenatal diagnosis of fetal skeletal dysplasia with 3D CT. Pediatric radiology, 42(7), 842-852. doi: 10.1007/s00247-012-2381-7

[12] Muzurova, L. V. (2011). Anthropometric characteristics of the chest of young men of various somatic types. Saratov Journal of Medical Science Macro - and Micromorphology, 7(1), 1417.

[13] Myer, G. D., Jayanthi, N., Difiori, J. P., Faigenbaum, A. D., Kiefer, A. W., Logerstedt, D., \& Micheli, L. J. (2015). Sport specialization, part I: does early sports specialization increase negative outcomes and reduce the opportunity for success in young athletes? Sports Health, 7(5), 437-442. doi: 10.1177/ 1941738115598747

[14 Peterson, J., Kaarma, H., \& Koskel, S. (2012). An anthropometric model for nutrition research of Estonian female students. Papers on Anthropology, 21, 201-211. doi: 10.12697/ poa.2012.21.17

[15] Pezala, M., \& Zukow, W. (2013). Somatic Features of Women's Volleyball Players Elementary School No. 31 in Bydgoszcz. Journal of Health Sciences, 3(6), 7-18.

[16] Pyatunina, O. I. (2009). The development of chest parameters in adolescents $11-15$ years of various body types. Scientific notes ZabGGPU, 1, 149-151.

[17] Raschka, C., \& Aichele, S. K. (2014). Correlations between somatotypes and nutritional intake in sports students. Papers on Anthropology, 23(2), 96-104. doi: 10.12697/ poa.2014.23.2.09

[18] Raschka, C., \& Beyer, K. (2015). Sports anthropological and somatotypical investigation of male and female Latin dancers. Papers on Anthropology, 24(2), 94-101. doi: 10.12697/ poa.2015.24.2.08

[19] Raschka, C., \& Graczyk, J. (2013). Correlations between somatotypes and nutritional intake in members of a fitness studio. Papers on Anthropology, 22, 145-152. doi: 10.12697/ poa.2013.22.16

[20] Sarafinyuk, L. A., Fomina, L. V., Khavtur, V. O., Fedoniuk, L. la., Khapitska, O. P., \& Stefanenko, I. S. (2018). Features of total body sizes and anthropometric body sizes in volleyball players of mesomorphic somatotype. Reports of Morphology, 24(3), 32-36. doi: 10.31393/morphology-journal-2018-24(3)-05

[21] Sarafinyuk, L. A., Khapitska, O. P., Yakusheva, Y. I., Ivanytsia, A. O., \& Sarafinyuk, P. V. (2018). Somatotypological features of acrobat girls in different periods of ontogenesis. Biomedical and Biosocial Anthropology, 32, 43-47. doi: 10.31393/bba322018-06

[22] Strohman, R. (2002). Maneuvering in the complex path from genotype to phenotype. Science, 296(5568), 701-703. doi: 10.1126/science.1070534

[23] Victoria, T., Epelman, M., Coleman, B. G., Horii, S., Oliver, E. R., Mahboubi, S., ... Jaramillo, D. (2013). Low-dose fetal CT in the prenatal evaluation of skeletal dysplasias and other severe skeletal abnormalities. American Journal of Roentgenology, 200(5), 989-1000. doi: org/10.2214/AJR.12.9722

[24] Tkachuk, M. G., Dusenova, A. A., Gruzdeva, N. S., \& Sobolev, A. A. (2012). Morphological criteria of sports selection in martial. Morphology, 3, 156.

[25] Wiersma, L. D. (2000). Risks and benefits of youth sport specialization: Perspectives and recommendations. Pediatric exercise science, 12(1), 13-22. doi: 10.1123/pes.12.1.13

[26] Yakusheva, Y. I., \& Sarafinyuk, L. A. (2014). Features of total and separate partial anthropometric sizes in volleyball players of adolescence. Reports of Morphology, 20(2), 473-475.

\section{ОСОБЛИВОСТІ РОЗМІРІВ ГРУДНОї КЛІТКИ У ВОЛЕЙБОЛІСТОК РІЗНИХ КОНСТИТУЦІОНАЛЬНИХ ТИПІВ}

Сарафинюк Л. А., Півторак В. І., Хавтур В. О., Федонюк Л. Я., Хапіцька О. П.

При проведенні кваліфікованого спортивного відбору у окремий вид спорту особливу увагу необхідно приділяти тим рисам та здібностям, які однозначно впливають на результативність, і тим, які переважно знаходяться під впливом генетичних факторів. До таких морфогенетичних маркерів спортивного відбору, у першу чергу, належать конституціональні особливості спортсменів, зокрема форма грудної клітки. Мета роботи - встановити відмінності антропометричних розмірів грудної клітки між волейболістками високого рівня спортивної майстерності та неспортсменками, які належали до різних конституціональних типів. На базі науково-дослідного центру Вінницького національного медичного університету ім. М. І. Пирогова проведене антропо-соматотипологічне дослідження 113 волейболісток високого рівня спортивної майстерності юнацького віку (від 16 до 20 років). Контрольну групу склали 204 практично здорових дівчат того ж віку, які не займалися спортом. Антропометричне вимірювання проводили за методом В. В. Бунака (1941), соматотипологічне дослідження - за розрахунковою модифікацією метода Heath-Carter (1990). У дівчат, які не займалися спортом, більше ніж у половині випадків зустрічалися конституціональні типи, для яких характерним було добрий розвиток жирової складової статури тіла. У волейболісток переважали особи з мезоморфннм соматотипом (26,66\%), а ектоморфи (23,01\%), ектомезоморфи (23,89\%) і представниці середнього проміжного соматотипу (23,01\%) у вибірці були представлені майже рівномірно. Аналіз отриманих результатів проведено у ліцензійному пакеті "Statistica 5.5" з використанням непараметричних методів оцінки показників. Нами встановлено, що волейболістки ектоморфного соматотипу мають найменші антропометричні розміри грудної клітки, порівняно з спортсменками інших конституціональних груп. У волейболісток мезоморфів всі поперечні, більшість обхватних розмірів грудної клітки були найбільшими. Спортсменки з екто-мезоморфним соматотипом незначно поступалися за величиною соматометричних параметрів мезоморфам, але у них були найбільші середні значення передньо-заднього розміру грудної клітки. Волейболістки з середнім проміжним соматотипом мали більші 
середні значення розмірів грудної клітки, ніж волейболістки з ектоморфним соматотипом, хоча достовірної різниці при їх порівнянні не виявлено. Виявлено, що більшість обхватних, поперечних і передньо-задніх розмірів грудної клітки у волейболісток статистично значуще більші, ніж у дівчат, які не займалися спортом $і$ належали до того ж конституціонального типу, що і спортсменки. Можна зробити висновок, що належність до одного конституціонального типу не забезпечує подібність морфометричних параметрів грудної клітки в осіб з різним рівнем фізичного навантаження. Ключові слова: грудна клітка, антропометрія, соматотип, волейболістки, юнацький вік.

\section{ОСОБЕННОСТИ РАЗМЕРОВ ГРУДНОЙ КЛЕТКИ У ВОЛЕЙБОЛИСТОК РАЗЛИЧНЫХ КОНСТИТУЦИОНАЛЬНЫХ ТИПОВ}

Сарафинюк Л. А., Пивторак В. И., Хавтур В. О., Федонюк Л. Я., Хапицкая О. П.

При проведении квалифицированного спортивного отбора в отдельный вид спорта особое внимание необходимо уделять тем характеристикам и возможностям, которые однозначно влияют на результативность, и тем, которые в основном находятся под влиянием генетических факторов. К таким морфогенетических маркерам спортивного отбора, в первую очередь, принадлежат конституциональные особенности спортсменов, в том числе форма грудной клетки. Цель работы - установить различия антропометрических размеров грудной клетки между волейболистками высокого уровня спортивного мастерства и неспортсменками, принадлежащими к разным конституциональным типам. На базе научноисследовательского центра Винницкого национального медицинского университета им. Н. И. Пирогова проведено антропосоматотипологическое исследование 113 волейболисток высокого уровня спортивного мастерства юношеского возраста (от 16 до 20 лет). Контрольную группу составили 204 практически здоровых девушек того же возраста, которые не занимались спортом. Антропометрические измерения проводили по методу В. В. Бунака (1941), соматотипологическое исследование - по расчетной модифрикации метода Heath-Carter (1990). У девушек, которые не занимались спортом, больше чем в половине случаев встречались конституциональные типы, для которых характерно хорошее развитие жировой составляющей телосложения. У волейболисток преобладали лица с мезоморфным соматотипом (26,66\%), а эктоморфы (23,01\%), экто-мезоморфы (23,89\%) и представительницы среднего промежуточного соматотипа (23,01\%) в выборке были представлены почти равномерно. Анализ полученных результатов проведен в лицензионном пакете "Statistica 5.5" c использованием непараметрических методов оценки показателей. Нами установлено, что волейболистки эктоморфного соматотипа имеют наименьшие антропометрические размеры грудной клетки по сравнению со спортсменками других конституциональных групп. У волейболисток мезоморфов все поперечные, большинство охватных размеров грудной клетки были наибольшими. Спортсменки с экто-мезоморфным соматотипом незначительно уступали по величине соматометрических параметров мезоморфам, но у них были наибольшие средние значения переднезаднего размера грудной клетки. Волейболистки со средним промежуточным соматотипом имели большие средние значения размеров грудной клетки, чем волейболистки с эктоморфрным соматотипом, хотя достоверной разницы при их сравнении не обнаружено. Выявлено, что большинство охватных, поперечных и передне-задних размеров грудной клетки у волейболисток статистически значимо больще, чем у девушек, которые не занимались спортом и принадлежали к тому же конституциональному типу, что и спортсменки. Можно сделать вывод, что принадлежность к одному конституциональному типу не обеспечивает сходство морфометрических параметров грудной клетки у лиц с разным уровнем фризической нагрузки.

Ключевые слова: грудная клетка, антропометрия, соматотип, волейболистки, юношеский возраст. 